Vol. 7(1998): 329-343.

\title{
Effects of and interactions between the extent of silage fermentation and protein supplementation in lactating dairy cows
}

Terttu Heikkilä, Vesa Toivonen and Pekka Huhtanen

Agricultural Research Centre of Finland, Institute of Animal Production, FIN-31600 Jokioinen,

Finland, e-mail: terttu.heikkila@mtt.fi

\begin{abstract}
Twelve Ayrshire cows were used to study the effects of and interactions between extent of silage fermentation and level of protein supplementation on silage intake and milk production. Experimental design was a cyclic change-over with six dietary treatments, with two replicate blocks of six cows and four 3-week periods. Dietary treatments in a $2 \times 3$ factorial arrangement consisted of two wilted silages treated with either a formic acid-based (FA) $5 \mathrm{l} / \mathrm{t}$ or a bacterial inoculant additive (I) and three levels of protein supplementation obtained by fish meal (FM) inclusion $(0,60$ and $120 \mathrm{~g} / \mathrm{kg}$ concentrate). Grass silage was given ad libitum and concentrates were offered at a rate of $10 \mathrm{~kg} / \mathrm{d}$. Both silages were well-preserved but I-silage was more extensively fermented than FA-silage. Feeding FA-silage decreased diet organic matter digestibility, particularly that of neutral detergent fibre, compared with I-silage. Inclusion of FM increased the digestibility of all dietary constituents. Dry matter (DM) intake of I-silage was lower than that of FA-silage but milk yield was not significantly affected. Restricting silage fermentation increased milk fat content, fat yield and energy corrected milk yield. FM inclusion increased silage DM intake, milk yield, milk protein content and yield. $\mathrm{FM}_{120}$ inclusion increased milk fat yield more with FA-silage than with I-silage, whereas the response in milk protein yield was greater with I-silage. Plasma glucose, plasma urea and milk urea concentrations were lower and blood $\beta$-hydroxybutyrate higher in cows given FA-diets than those given I-diets.
\end{abstract}

Key words: bacterial inoculant, digestibility, fish meal, formic acid, milk composition, milk production, silage intake, wilted silage

\section{Introduction}

Extent of silage fermentation can be modified by additives and wilting. Restriction of fermentation can be achieved by using formic acid or other acids at high levels of application. Fermentation is stimulated by inoculants of lactic acid bacteria, enzymes or by fermentable carbohydrates added during ensiling. Wilting herbage generally reduces the extent of fermentation (van Vuuren et al. 1995). Modifications in the chemical composition during ensilage can alter the supply of nutrients from the digestive tract both quantitatively and qualitatively, which affect both milk yield and composition (Chamberlain 


\section{AGRICULTURAL AND FOOD SCIENCE IN FINLAND}

Heikkilä, T. et al. Extent of silage fermentation and protein supplementation in cows

and Choung 1993, van Vuuren et al. 1995). Lactic acid in silage increases the molar proportion of propionate in the rumen, whereas water soluble carbohydrates (WSC) in silage increase lipogenic volatile fatty acids (VFA, Jaakkola et al. 1991, 1993, Robertson et al. 1993, Martin et al. 1994). Silage fermentation acids have limited value as an energy source for rumen microbes (Chamberlain 1987), and increased fermentation in the silo has resulted in a reduced efficiency of rumen microbial protein synthesis (Jaakkola et al. 1991, 1993, Robertson et al. 1993).

In many of our studies where enzymes or enzymes and bacterial inoculants have been used for direct cut material, extensive fermentation has markedly reduced silage DM intake, and consequently production (e.g. Heikkilä et al. $1989,1993)$ compared with formic acid-treated silages. The purpose of this study was to investigate the effectiveness of an inoculant additive in wilted silage compared with formic acid and, in addition study interactions between the extent of silage fermentation and protein supplementation, since the protein value of extensively fermented silages have been shown to be less than that of restrictively fermented silages (Jaakkola et al. 1991, 1993). Different levels of fish meal were used as a protein supplement.

\section{Material and methods}

\section{Silages}

Silages were made on 7 June 1993 from the primary growth of a timothy (Phleum pratense) and meadow fescue (Festuca pratensis) sward, fertilized with 90-18-36 kg N-P-K/ha. Grass was cut with a mower-conditioner and harvested, after wilting for 4-6 h, using a precision-chop forage harvester. Grass was ensiled in two roofed bunker silos of $50 \mathrm{t}$ capacity with either a formic acid-based additive (FA, $800 \mathrm{~g} / \mathrm{kg}$ formic acid and $20 \mathrm{~g} / \mathrm{kg}$ orthophosphoric acid) at $5 \mathrm{l} / \mathrm{t}$ or with a bacterial inoculant (I), which was a mixture of Lactobacillus rhamnosus and Propionibacterium freudenreichii ssp. shermanii (Valio Ltd), at $5 \times 10^{6}$ colony forming units/g grass. During harvesting, temperature, wind and relative humidity were between $11-17^{\circ} \mathrm{C}, 3.1-5.7 \mathrm{~m} / \mathrm{s}$ and $45-74 \%$, respectively. Silos were opened after 266 days. Aerobic stability of silages was assessed by loosely packing duplicate $5 \mathrm{~kg}$ samples, with four repetitions per treatment, in polythene-lined styrox boxes $(40 \times 28 \times 28 \mathrm{~cm}, 2.5$ $\mathrm{cm}$ thick) fitted with partly open lids. Silage boxes were incubated for 10 days at $16^{\circ} \mathrm{C}$. Temperature was measured twice daily.

\section{Animals and their management}

Twelve high-yielding Finnish Ayrshire cows in their 2nd-4th lactation were used. Cows had calved 48 days (SE 4.5) before the start of the experiment and their average daily milk yield was $36.5 \mathrm{~kg}$ (SE 0.4). Cows were housed in individual stalls. Grass silages were offered ad libitum ensuring a refusal of at least $50 \mathrm{~g} / \mathrm{kg}$ intake. Concentrate mixtures were given at a rate of $10 \mathrm{~kg} / \mathrm{d}$ throughout the experiment three times daily at 0100,1300 and 1630 . Cows were milked twice daily at 0645 and 1530 . Animals were weighed on two consecutive days at the beginning of the experiment and at the end of each period.

\section{Experimental design}

The study was conducted according to a cyclic change-over design with six treatments in a $2 \times$ 3 factorial arrangement, with two replicate blocks of six cows and four 3-week experimental periods (Davis and Hall 1969). Treatments consisted of two silages (FA-treated and I-treated) each fed with three concentrate supplements differing in their crude protein content (CP, 129, 169 , and $211 \mathrm{~g} / \mathrm{kg} \mathrm{DM})$. The basal concentrate $\left(\mathrm{FM}_{0}\right)$ contained $(\mathrm{g} / \mathrm{kg})$ barley (382), oats (382), molassed sugar beet pulp (200) and mineral mix- 


\section{AGRICULTURAL AND FOOD SCIENCE IN FINLAND}

Vol. 7 (1998): 329-343.

ture (36), of which either $60\left(\mathrm{FM}_{60}\right)$ or 120 $\left(\mathrm{FM}_{120}\right) \mathrm{g} / \mathrm{kg}$ was replaced with fish meal (FM).

\section{Experimental procedures, chemical and statistical analyses}

Feed intake and milk yield of individual cows were recorded daily. The results of the last seven days of each period were used for statistical analysis, and feed samples were collected during this period for chemical analysis. Fresh silage samples were stored frozen at $-20^{\circ} \mathrm{C}$ prior to analysis. Milk samples, in proportion to yield, were taken on four consecutive milkings on the last week of each period. Diet digestibility was determined using acid insoluble ash (AIA) as an internal marker. Faecal samples were taken from all cows twice daily at 0730 and 1600 . Blood samples were taken prior to feeding and $4 \mathrm{~h}$ after feeding on the last day of each period from the coccygeal vessel of each cow. Each sample was analysed for glucose, $\beta$-hydroxybutyrate (BHB) and urea.

Chemical analyses of milk, feed and faecal samples were made as described previously by Huhtanen and Heikkilä (1996). Silage ethanol content was determined according to Huida (1982). Blood samples were treated and analysed as described by Miettinen and Huhtanen (1997).

Intake of metabolizable energy (ME) was estimated from organic matter (OM) intake and digestibility determined using AIA as a marker and assuming a ME content of $16 \mathrm{MJ} / \mathrm{kg}$ digestible OM (MAFF 1984). ME contents of silages were also estimated from D-values (digestible organic matter in DM) determined in three sheep fed at a maintenance level. ME of concentrates were derived from chemical composition and digestibility coefficients documented in Finnish feed tables (Tuori et al. 1996). Utilisation of ME for milk production was calculated ignoring the effects of live weight change. The supply of amino acids absorbed from the small intestine (AAT) was calculated based on feed table values (Tuori et al. 1996) for each feed or feed ingredient.
Data was analysed using the general linear model directive of the Statistical Analysis System (SAS Institute Inc. 1989). The model included block, cow(block), period, treatment and carry-over. Results for production parameters are adjusted for carry-over effects. Data of one cow was removed due to mastitis and gastrointestinal disorders. Sum of squares of the treatment effect was further separated into orthogonal comparisons of the effects of silage type (FA vs. I), linear and quadratic effects of the protein content of concentrates (FM inclusion) and corresponding interactions.

\section{Results}

Both silages were well-preserved as indicated by low concentrations of VFA and ammonia N (Table 1). Propionate was not found in I-silage, although the inoculant contained Propionibacterium. Inoculated silage was more fermented than FA-silage in terms of a lower $\mathrm{pH}$ and higher lactic acid content. Lactate to acetate ratio was higher in I-silage than in FA-silage ( 28 vs. 2.7 ) indicating the fermentation being almost homofermentative. Neutral detergent fibre (NDF) content was slightly higher in I-treated silage compared with FA-treated silage. The aerobic stability of FA-silage compared with I-silage was better as indicated by a slower temperature increase (Figure 1).

The intake of silage DM was higher $(\mathrm{P}<0.05)$ in cows given FA-treated silage than in those given I-treated silage (Table 2). Increasing dietary CP content by FM inclusion increased silage DM intake linearly $(\mathrm{P}<0.01)$. However, because the amount of concentrate refusals increased at the same time, differences in total DM intake only approached significance $(\mathrm{P}=0.09)$. Silage type had no effect on calculated ME intake, whereas both ME and AAT supply increased linearly (at least $\mathrm{P}<0.01$ ) with supplement protein content. 


\section{AGRICULTURAL AND FOOD SCIENCE IN FINLAND}

Heikkilä, T. et al. Extent of silage fermentation and protein supplementation in cows

Table 1. Chemical composition ( $\mathrm{g} / \mathrm{kg}$ dry matter) and calculated feeding values of experimental feeds.

\begin{tabular}{|c|c|c|c|c|c|}
\hline & \multicolumn{2}{|c|}{ Silages } & \multicolumn{3}{|c|}{ Supplements } \\
\hline & FA-treated & I-treated & $\mathrm{FM}_{0}$ & $\mathrm{FM}_{60}$ & $\mathrm{FM}_{120}$ \\
\hline Dry matter $(\mathrm{g} / \mathrm{kg})$ & 313 & 322 & 889 & 889 & 889 \\
\hline $\mathrm{pH}$ & 4.34 & 3.85 & ND & ND & ND \\
\hline \multicolumn{6}{|l|}{ In dry matter } \\
\hline Ash & 77 & 75 & 65 & 66 & 69 \\
\hline Crude protein & 160 & 157 & 129 & 169 & 211 \\
\hline Ether extract & 43 & 57 & 33 & 37 & 39 \\
\hline $\mathrm{NDF}^{1}$ & 458 & 477 & 278 & 285 & 291 \\
\hline $\mathrm{ADF}^{2}$ & 259 & 260 & 103 & 102 & 97 \\
\hline $\mathrm{WSC}^{3}$ & 160 & 61 & ND & ND & ND \\
\hline Lactic acid & 35 & 132 & ND & ND & ND \\
\hline Acetic acid & 13.2 & 4.8 & ND & ND & ND \\
\hline Butyric acid & 0.2 & 0.1 & ND & ND & ND \\
\hline Isovaleric acid & 0.7 & 0.3 & ND & ND & ND \\
\hline Ethanol & 6.8 & 5.2 & ND & ND & ND \\
\hline \multicolumn{6}{|l|}{ In total $\mathrm{N}(\mathrm{g} / \mathrm{kg})$} \\
\hline Ammonia $\mathrm{N}$ & 38 & 38 & ND & ND & ND \\
\hline Soluble N & 635 & 680 & ND & ND & ND \\
\hline $\mathrm{ME}^{4}(\mathrm{MJ} / \mathrm{kg} \mathrm{DM})$ & 11.4 & 11.4 & 12.6 & 12.7 & 12.7 \\
\hline $\mathrm{AAT}^{5}(\mathrm{~g} / \mathrm{kg} \mathrm{DM})$ & 87 & 85 & 101 & 116 & 130 \\
\hline $\mathrm{PBV}^{6}(\mathrm{~g} / \mathrm{kg} \mathrm{DM})$ & 12 & 11 & -35 & -16 & 5 \\
\hline
\end{tabular}

$\mathrm{FA}=$ formic acid, $\mathrm{I}=$ inoculant, $\mathrm{FM}=$ fish meal, $\mathrm{ND}=$ not determined.

' Neutral detergent fibre.

${ }^{2}$ Acid detergent fibre.

${ }^{3}$ Water soluble carbohydrates.

${ }^{4}$ Calculated from D-value determined in sheep for silage and from feed table digestibility coefficients for concentrates (Tuori et al. 1996).

${ }^{5}$ Amino acids absorbed from the small intestine

${ }^{6}$ Protein balance value.

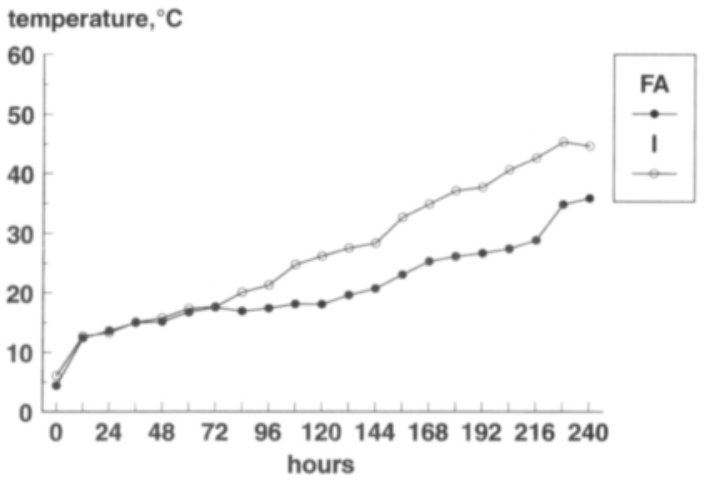

Figure 1. Effects of formic acid and inoculant additives on aerobic stability of silages.
Silage type had no significant effect on milk yield or feed efficiency (Table 3). However, due to the higher $(\mathrm{P}<0.001)$ milk fat content in cows receiving FA-treated silage compared with those given I-silage, yields of fat $(\mathrm{P}<0.01)$ and energy corrected milk (ECM, $\mathrm{P}=0.051$ ) were higher. Milk protein content and yield were not significantly influenced by the type of silage. Milk lactose content was lower $(\mathrm{P}<0.001)$ with FA-silage than with $\mathrm{I}$-silage resulting in a higher $(\mathrm{P}=0.054)$ lactose yield in favour of I-silage.

The response to FM depended on the fermentation of silage, indicated by a silage $x$ fish meal interaction $(\mathrm{P}<0.05)$ in most production param- 


\section{AGRICULTURAL AND FOOD SCIENCE IN FINLAND}

Vol. 7 (1998): 329-343.

Table 2. Feed intake and calculated nutrient intake of cows receiving formic acid-treated (FA) or inoculated (I) silages supplemented with different levels of fish meal (FM).

\begin{tabular}{|c|c|c|c|c|c|c|c|c|c|c|c|c|}
\hline \multirow{2}{*}{$\begin{array}{l}\text { Supplement } \\
\text { Silage }\end{array}$} & \multicolumn{2}{|c|}{$\mathrm{FM}_{0}$} & \multicolumn{2}{|c|}{$\mathrm{FM}_{60}$} & \multicolumn{2}{|c|}{$\mathrm{FM}_{120}$} & \multirow{2}{*}{ SEM } & \multicolumn{5}{|c|}{ Significance of effect ${ }^{1}$} \\
\hline & FA & I & FA & I & FA & I & & Silage & $\mathrm{FM}_{\text {lin }}$ & $\mathrm{FM}_{\text {quad }}$ & $\begin{array}{c}\text { Silage } \times \\
\text { FM }_{\text {lin }}\end{array}$ & $\begin{array}{l}\text { Silage } \times \\
\text { FM }_{\text {quad }}\end{array}$ \\
\hline \multicolumn{13}{|c|}{ Intake (kg DM/d) } \\
\hline Silage & 13.01 & 12.41 & 13.26 & 12.80 & 13.78 & 13.25 & 0.237 & * & $* *$ & NS & NS & NS \\
\hline Concentrate & 8.85 & 8.99 & 8.73 & 8.81 & 8.33 & 8.66 & & & & & & \\
\hline Total & 21.86 & 21.40 & 21.99 & 21.61 & 22.11 & 21.91 & 0.159 & * & o & NS & NS & NS \\
\hline \multicolumn{13}{|l|}{ Crude protein } \\
\hline $\mathrm{NDF}^{2}(\mathrm{~kg} / \mathrm{d})$ & $\begin{array}{l}3.52 \\
7.79\end{array}$ & 7.83 & 7.97 & $\begin{array}{l}8.00 \\
8.14\end{array}$ & 8.05 & $\begin{array}{l}4.00 \\
8.21\end{array}$ & $\begin{array}{l}0.002 \\
0.093\end{array}$ & NS & $* *$ & NS & NS & NS \\
\hline $\mathrm{ME}(\mathrm{MJ} / \mathrm{d})^{3}$ & 237 & 237 & 241 & 241 & 242 & 248 & 2.2 & NS & $* *$ & NS & NS & NS \\
\hline $\operatorname{AAT}(\mathrm{g} / \mathrm{d})^{4}$ & 2009 & 1976 & 2070 & 2042 & 2175 & 2174 & 12.7 & o & $* * *$ & o & NS & NS \\
\hline
\end{tabular}

'Significance: NS $(\mathrm{P}>0.10)$, o $(\mathrm{P}<0.10),{ }^{*}(\mathrm{P}<0.05),{ }^{* *}(\mathrm{P}<0.01),{ }^{* * *}(\mathrm{P}<0.001)$

${ }^{2}$ Neutral detergent fibre

3 Calculated from the intake of digestible OM determined in cows using AIA as an internal marker

${ }^{4}$ Calculated using for all feeds EPD-values from feed tables (Tuori et al. 1996)

Table 3. Milk production, live weight and feed efficiency of cows receiving formic acid-treated (FA) or inoculated (I) silages supplemented with different levels of fish meal (FM).

\begin{tabular}{|c|c|c|c|c|c|c|c|c|c|c|c|c|}
\hline \multirow{2}{*}{$\begin{array}{l}\text { Supplement } \\
\text { Silage }\end{array}$} & \multicolumn{2}{|c|}{$\mathrm{FM}_{0}$} & \multicolumn{2}{|c|}{$\mathrm{FM}_{60}$} & \multicolumn{2}{|c|}{$\mathrm{FM}_{120}$} & \multirow{2}{*}{ SEM } & \multicolumn{5}{|c|}{ Significance of effect ${ }^{1}$} \\
\hline & FA & I & FA & I & FA & I & & Silage & $\mathrm{FM}_{\operatorname{lin}}$ & $\mathrm{FM}_{\text {quad }}$ & $\begin{array}{c}\text { Silage } \times \\
F_{\text {lin }}\end{array}$ & $\begin{array}{l}\text { Silage } \times \\
F_{\text {quad }}\end{array}$ \\
\hline Milk (kg/d) & 33.3 & 32.8 & 31.9 & 33.7 & 34.3 & 34.0 & 0.37 & NS & * & * & NS & * \\
\hline $\mathrm{ECM}^{2}(\mathrm{~kg} / \mathrm{d})$ & 36.0 & 34.9 & 35.0 & 35.2 & 38.1 & 36.1 & 0.50 & o & $*$ & * & $*$ & NS \\
\hline \multicolumn{13}{|c|}{ Milk composition $(\mathrm{g} / \mathrm{kg})$} \\
\hline Fat & 46.2 & 44.9 & 46.7 & 43.1 & 48.3 & 44.0 & 0.87 & $* * *$ & NS & NS & * & * \\
\hline Protein & 32.2 & 31.5 & 33.7 & 32.7 & 33.1 & 33.4 & 0.33 & NS & ** & o & NS & NS \\
\hline Lactose & 50.3 & 50.7 & 49.5 & 50.8 & 49.7 & 50.0 & 0.19 & $* * *$ & ** & NS & NS & ** \\
\hline Milk urea (mmol & l/l) 2.96 & 3.56 & 4.08 & 4.66 & 4.88 & 5.81 & 0.100 & *** & $* * *$ & NS & NS & NS \\
\hline \multicolumn{13}{|c|}{ Milk constituents (g/d) } \\
\hline Fat & 1530 & 1468 & 1492 & 1437 & 1652 & 1491 & 33.3 & ** & o & o & ** & NS \\
\hline Protein & 1071 & 1033 & 1071 & 1094 & 1131 & 1133 & 10.6 & NS & $* * *$ & NS & NS & o \\
\hline Lactose & 1676 & 1665 & 1580 & 1719 & 1704 & 1700 & 22.3 & o & NS & NS & NS & ** \\
\hline \multicolumn{13}{|c|}{ Feed efficiency } \\
\hline \multicolumn{13}{|c|}{ Milk protein/CP intake } \\
\hline$(\mathrm{g} / \mathrm{kg})$ & 323 & 317 & 290 & 298 & 282 & 279 & 4.0 & NS & $* * *$ & o & NS & o \\
\hline \multicolumn{13}{|l|}{ Live weight } \\
\hline Mean (kg) & 590 & 583 & 590 & 591 & 593 & 591 & 2.2 & NS & * & NS & NS & o \\
\hline change $(\mathrm{kg} / \mathrm{d})$ & -0.01 & -0.33 & -0.07 & 0.24 & 0.53 & 0.56 & 0.164 & NS & $* * *$ & NS & NS & NS \\
\hline
\end{tabular}

' Significance: NS $(\mathrm{P}>0.10)$, o $(\mathrm{P}<0.10),{ }^{*}(\mathrm{P}<0.05),{ }^{* *}(\mathrm{P}<0.01),{ }^{* * *}(\mathrm{P}<0.001)$

${ }^{2} \mathrm{ECM}=$ energy corrected milk (Sjaunja et al. 1990). ${ }^{3} \mathrm{CP}=$ crude protein 


\section{AGRICULTURAL AND FOOD SCIENCE IN FINLAND}

Heikkilä, T. et al. Extent of silage fermentation and protein supplementation in cows

Table 4. Milk fatty acid composition ( $\mathrm{g} / \mathrm{kg}$ fatty acids) in cows receiving formic acid-treated (FA) or inoculated (I) silages supplemented with different levels of fish meal (FM).

\begin{tabular}{|c|c|c|c|c|c|c|c|c|c|c|c|c|}
\hline \multirow{2}{*}{$\begin{array}{l}\text { Supplement } \\
\text { Silage }\end{array}$} & \multicolumn{2}{|c|}{$\mathrm{FM}_{0}$} & \multicolumn{2}{|c|}{$\mathrm{FM}_{60}$} & \multicolumn{2}{|c|}{$\mathrm{FM}_{120}$} & \multirow{2}{*}{ SEM } & \multicolumn{5}{|c|}{ Significance of effect ${ }^{1}$} \\
\hline & FA & I & FA & I & FA & I & & Silage & $\mathrm{FM}_{\text {tin }}$ & $\mathrm{FM}_{\mathrm{quad}}$ & $\begin{array}{l}\text { Silage } \times \\
\text { FM }_{\text {lin }}\end{array}$ & $\begin{array}{l}\text { Silage } \times \\
F_{\text {quad }}\end{array}$ \\
\hline $\mathrm{C}_{4}$ & 57 & 55 & 55 & 51 & 57 & 54 & 1.2 & * & NS & * & NS & NS \\
\hline $\mathrm{C}_{6}$ & 31 & 31 & 31 & 30 & 31 & 31 & 0.6 & NS & NS & NS & NS & NS \\
\hline $\mathrm{C}_{8}^{6}$ & 17 & 18 & 18 & 18 & 18 & 18 & 0.4 & NS & NS & NS & NS & NS \\
\hline $\mathrm{C}_{10}^{8}$ & 37 & 41 & 40 & 42 & 38 & 44 & 1.3 & $* *$ & NS & NS & NS & NS \\
\hline $\mathrm{C}_{12}$ & 42 & 47 & 46 & 49 & 44 & 52 & 1.6 & $* * *$ & NS & NS & NS & NS \\
\hline $\mathrm{C}_{14}$ & 133 & 141 & 141 & 143 & 135 & 149 & 2.3 & $* * *$ & NS & NS & NS & o \\
\hline $\mathrm{C}_{14: 1}$ & 18 & 19 & 18 & 19 & 18 & 19 & 0.3 & $* *$ & NS & NS & NS & NS \\
\hline $\mathrm{C}_{4-} \mathrm{C}_{14: 1}$ total & 335 & 352 & 349 & 352 & 338 & 368 & 6.1 & $* *$ & NS & NS & NS & o \\
\hline $\mathrm{C}_{16-0}$ & 322 & 314 & 295 & 317 & 313 & 306 & 7.0 & NS & NS & NS & NS & * \\
\hline$C_{16: 1}$ & 24 & 24 & 25 & 24 & 24 & 25 & 0.5 & NS & NS & NS & NS & NS \\
\hline$C_{18.0}^{10.17}$ & 106 & 102 & 106 & 100 & 101 & 90 & 2.7 & * & * & NS & NS & NS \\
\hline$C_{18: 1}^{18.0}$ & 180 & 176 & 184 & 170 & 182 & 169 & 5.4 & * & NS & NS & NS & NS \\
\hline $\mathrm{C}_{18.2}$ & 23 & 22 & 24 & 22 & 24 & 22 & 0.7 & ** & NS & NS & NS & NS \\
\hline
\end{tabular}

' Significance: NS $(\mathrm{P}>0.10), \mathrm{o}(\mathrm{P}<0.10),{ }^{*}(\mathrm{P}<0.05),{ }^{* *}(\mathrm{P}<0.01),{ }^{* * *}(\mathrm{P}<0.001)$

Table 5. Whole tract nutrient digestibility of formic acid-treated (FA) or inoculated (I) silage based diets supplemented with different levels of fish meal (FM).

\begin{tabular}{|c|c|c|c|c|c|c|c|c|c|c|c|c|}
\hline \multirow{2}{*}{$\begin{array}{l}\text { Supplement } \\
\text { Silage }\end{array}$} & \multicolumn{2}{|c|}{$\mathrm{FM}_{0}$} & \multicolumn{2}{|c|}{$\mathrm{FM}_{60}$} & \multicolumn{2}{|c|}{$\mathrm{FM}_{120}$} & \multirow{2}{*}{ SEM } & \multicolumn{5}{|c|}{ Significance of effect ${ }^{1}$} \\
\hline & FA & I & FA & I & FA & I & & Silage & $\mathrm{FM}_{\operatorname{lin}}$ & $\mathrm{FM}_{\text {quad }}$ & $\begin{array}{l}\text { Silage } \times \\
\mathrm{FM}_{\text {lin }}\end{array}$ & $\begin{array}{l}\text { Silage } \times \\
\mathrm{FM}_{\text {quad }}\end{array}$ \\
\hline Dry matter & 0.716 & 0.732 & 0.725 & 0.736 & 0.726 & 0.750 & 0.0035 & $* * *$ & $* * *$ & NS & NS & o \\
\hline Organic matter & 0.729 & 0.745 & 0.740 & 0.749 & 0.742 & 0.765 & 0.0035 & $* * *$ & $* * *$ & NS & NS & o \\
\hline Crude protein & 0.676 & 0.693 & 0.699 & 0.719 & 0.715 & 0.747 & 0.0060 & $* * *$ & $* * *$ & NS & NS & NS \\
\hline $\begin{array}{l}\text { Neutral detergent } \\
\text { fibre }\end{array}$ & 0.575 & 0.621 & 0.618 & 0.649 & 0.623 & 0.671 & 0.0083 & $* * *$ & $* * *$ & NS & NS & NS \\
\hline
\end{tabular}

' Significance: NS $(\mathrm{P}>0.10), \mathrm{o}(\mathrm{P}<0.10),{ }^{*}(\mathrm{P}<0.05),{ }^{* *}(\mathrm{P}<0.01),{ }^{* * *}(\mathrm{P}<0.001)$

Table 6. Concentrations of blood metabolites (mmol/l) of cows receiving formic acid-treated (FA) or inoculated (I) silages supplemented with different levels of fish meal (FM).

\begin{tabular}{|c|c|c|c|c|c|c|c|c|c|c|c|c|}
\hline \multirow{2}{*}{$\begin{array}{l}\text { Supplement } \\
\text { Silage }\end{array}$} & \multicolumn{2}{|c|}{$\mathrm{FM}_{0}$} & \multicolumn{2}{|c|}{$\mathrm{FM}_{60}$} & \multicolumn{2}{|c|}{$\mathrm{FM}_{120}$} & \multirow{2}{*}{ SEM } & \multicolumn{5}{|c|}{ Significance of effect ${ }^{1}$} \\
\hline & $\mathrm{FA}$ & I & $\mathrm{FA}$ & I & $\mathrm{FA}$ & I & & Silage & $\mathrm{FM}_{\text {in }}$ & $\mathrm{FM}_{\text {quad }}$ & $\begin{array}{c}\text { Silage } \times \\
\text { FM }_{\text {lin }}\end{array}$ & $\begin{array}{l}\text { Silage } \times \\
\text { FM }_{\text {quad }}\end{array}$ \\
\hline \multicolumn{13}{|l|}{ Plasma } \\
\hline Glucose & 2.77 & 3.27 & 2.95 & 3.09 & 2.86 & 3.14 & 0.090 & $* * *$ & NS & NS & NS & NS \\
\hline Urea & 3.06 & 3.53 & 4.28 & 4.71 & 5.11 & 5.69 & 0.212 & o & $* * *$ & NS & NS & NS \\
\hline \multicolumn{13}{|l|}{ Blood } \\
\hline $\mathrm{BHB}^{2}$ & 1.27 & 0.83 & 1.39 & 0.94 & 1.37 & 1.02 & 0.113 & $* * *$ & NS & NS & NS & NS \\
\hline
\end{tabular}

${ }^{1}$ Significance: NS $(\mathrm{P}>0.10), \mathrm{o}(\mathrm{P}<0.10),{ }^{*}(\mathrm{P}<0.05),{ }^{* *}(\mathrm{P}<0.01),{ }^{* * *}(\mathrm{P}<0.001)$

${ }^{2} \beta$ - hydroxybutyrate 


\section{AGRICULTURAL AND FOOD SCIENCE IN FINLAND}

Vol. 7 (1998): 329-343.

Table 7. Utilisation of ME and amino acids absorbed from the small intestine (AAT) of cows receiving formic acid-treated (FA) or inoculated (I) silages supplemented with different levels of fish meal (FM).

\begin{tabular}{|c|c|c|c|c|c|c|c|c|c|c|c|c|}
\hline \multirow{2}{*}{$\begin{array}{l}\text { Supplement } \\
\text { Silage }\end{array}$} & \multicolumn{2}{|c|}{$\mathrm{FM}_{0}$} & \multicolumn{2}{|c|}{$\mathrm{FM}_{60}$} & \multicolumn{2}{|c|}{$\mathrm{FM}_{120}$} & \multirow{2}{*}{ SEM } & \multicolumn{5}{|c|}{ Significance of effect ${ }^{1}$} \\
\hline & FA & I & FA & I & FA & I & & Silage & $\mathrm{FM}_{\text {lin }}$ & $\mathrm{FM}_{\text {quax }}$ & $\begin{array}{l}\text { Silage } \times \\
\text { FM }_{\text {lin }}\end{array}$ & $\begin{array}{l}\text { Silage } \times \\
\mathrm{FM}_{\text {quad }}\end{array}$ \\
\hline $\begin{array}{l}\text { Milk energy } \\
\text { (ME/d) } \\
\text { Utilisation }\end{array}$ & 113.0 & 109.5 & 109.9 & 110.7 & 119.5 & 113.3 & 1.6 & * & $* *$ & NS & o & NS \\
\hline of $\mathrm{ME}$ & 0.645 & 0.624 & 0.612 & 0.618 & 0.664 & 40.608 & 0.010 & * & NS & o & $* *$ & NS \\
\hline $\begin{array}{l}\text { Utilisation } \\
\text { of AAT } \\
\text { AAT } \mathrm{g} / \mathrm{kg}\end{array}$ & 0.660 & 0.651 & 0.637 & 0.660 & 0.638 & 30.634 & 0.007 & NS & $*$ & NS & NS & o \\
\hline $\mathrm{ECM}^{2}$ & 45.1 & 45.7 & 48.3 & 47.1 & 47.0 & 49.6 & 0.71 & NS & $* *$ & NS & NS & o \\
\hline
\end{tabular}

' Significance: NS $(\mathrm{P}>0.10)$, o $(\mathrm{P}<0.10),{ }^{*}(\mathrm{P}<0.05),{ }^{* *}(\mathrm{P}<0.01),{ }^{* * *}(\mathrm{P}<0.001)$.

${ }^{2} \mathrm{ECM}=$ energy corrected milk (Sjaunja et al. 1990).

eters. FM supplementation increased linearly milk yield $(\mathrm{P}<0.05)$, milk protein content $(\mathrm{P}<0.01)$ and yield $(\mathrm{P}<0.001)$. The efficiency of the utilization of dietary $\mathrm{CP}$ for milk protein production decreased with the level of FM. Protein supplementation $\left(\mathrm{FM}_{0}\right.$ to $\left.\mathrm{FM}_{120}\right)$ tended to increase milk protein yield more with I-silage than with FA-silage (100 vs. $60 \mathrm{~g} / \mathrm{d}$ ), whereas it increased milk fat yield more with FA-silage than I-silage (122 vs. $23 \mathrm{~g} / \mathrm{d})$. The effect of silage type on milk fat content also depended on the level of FM supplementation (interactions $\mathrm{P}<0.05$ ); differences between FA- and I-silages increased from $1.3 \mathrm{~g} / \mathrm{kg}\left(\mathrm{FM}_{0}\right)$ to $3.6\left(\mathrm{FM}_{60}\right)$ and $4.3 \mathrm{~g} / \mathrm{kg}$ $\left(\mathrm{FM}_{120}\right)$. FM decreased $(\mathrm{P}<0.01)$ milk lactose content but as a result of increased milk yield, FM had no effect on lactose yield. The response in lactose yield to FM was slightly better with Isilage than with FA-silage, especially between the two lowest levels of FM. Milk urea content was higher $(\mathrm{P}<0.001)$ with I-silage than with FAsilage and increased linearly $(\mathrm{P}<0.001)$ with $\mathrm{FM}$ supplementation. Live weight gain was not significantly different between silages but FM increased it linearly and there was a tendency for a greater increase with I-silage (interaction $\mathrm{P}=0.115$ ).

Differences in milk fatty acid composition were small, although in many cases statistically significant (Table 4). Of the short chain fatty acids, the proportion of butyric acid was higher $(\mathrm{P}<0.05)$ in cows given FA-silage compared with those given I-silage while the reverse was true for $\mathrm{C}_{10}-\mathrm{C}_{14}$ fatty acids. FA-silage significantly (at least $\mathrm{P}<0.05$ ) increased the proportions of all $\mathrm{C}_{18}$ fatty acids. FM had very little effect on milk fatty acid composition and neither did it modify differences between silage types.

Apparent digestibilities of $\mathrm{OM}, \mathrm{N}$ and NDF were all significantly higher $(\mathrm{P}<0.001)$ with $\mathrm{I}$ silage compared with FA-silage (Table 5). The difference was largest in NDF digestibility $(0.605$ vs. 0.647$)$. Inclusion of FM significantly $(\mathrm{P}<0.001)$ increased digestibility of all dietary components.

Plasma glucose concentration was significantly higher $(\mathrm{P}<0.001)$ and that of blood $\mathrm{BHB}$ lower $(\mathrm{P}<0.001)$ with I-silage compared with FAsilage (Table 6). FM had no effect on either plasma glucose or blood BHB but plasma urea content increased linearly $(\mathrm{P}<0.001)$ with the level of FM inclusion. Plasma urea content tended to be higher $(\mathrm{P}<0.10)$ with $\mathrm{I}$-silage than FA-silage.

Milk energy yield was higher $(\mathrm{P}<0.05)$ with FA-silage than with I-silage (Table 7) and increased linearly $(\mathrm{P}<0.01)$ with the level of protein supplementation. Efficiency of utilization of energy for milk production averaged 0.628 ig- 


\section{AGRICULTURAL AND FOOD SCIENCE IN FINLAND}

\section{Heikkilä, T. et al. Extent of silage fermentation and protein supplementation in cows}

noring the effects of live weight change. It was significantly $(\mathrm{P}<0.05)$ higher in cows given FAsilage compared with those receiving I-silage (0.640 vs. 0.617). Differences between the silages in ME utilisation increased with protein supplementation (interaction $\mathrm{P}<0.01$ ). Both conversion of AAT for ECM production and utilisation of AAT for milk protein production decreased (at least $\mathrm{P}<0.05$ ) with the level of protein supplementation.

\section{Discussion}

\section{Effects of silage fermentation}

Due to wilting coupled with high WSC content $(158 \mathrm{~g} / \mathrm{kg} \mathrm{DM})$, it would be expected that the material was relatively easy to ensile. Formic acid restricted silage fermentation efficiently as indicated by high residual WSC and lower lactic acid contents compared with I-treated silage. Very high lactate to acetate ratio of the I-treated silage suggests that the inoculant dominated fermentation over epiphytic lactic acid bacteria which are often more heterofermentative. Formic acid inhibits the growth of Lactobacilli in the initial phase of fermentation (Chamberlain and Quig 1987) as was also shown with the present silages by Rauramaa et al. (1996). A lower lactate to acetate ratio in FA-silage compared with I-silage indicated heterofermentative characteristics of surviving epiphytic lactic acid bacteria. The higher acetate concentration in FA-silage than in I-silage is in accord with previous data (Gordon 1989, Mayne 1993). The absence of propionic acid indicates that Propionibacterium was not active in the acidic conditions of Isilage.

The effects of formic acid on aerobic stability of silage have been inconsistent. The better aerobic stability of FA-silage compared with inoculated silage is in agreement with results of Mayne (1993) and Keady and Murphy (1996, 1997), who used lower levels of FA application.
In contrast, Keady and Murphy (1997) found reduced aerobic stability with a high level of FA.

In agreement with the study of Huhtanen et al. (1997b), in which digestibility of diets based on the same silages was determined by the total collection method in dairy cows, feeding I-diets improved digestibility compared with FA-diets. Differences in OM digestibility can almost entirely be attributed to the lower NDF digestibility of FA-silage. Also in the study of Keady and Murphy (1997), NDF digestibility was decreased with high levels of FA application compared with inoculated silage. On the other hand, Gordon (1989) working with sheep reported that the Dvalue of inoculated silage was higher compared to that of untreated and FA-treated silage in the absence of differences in silage fermentation. The reason for the lower digestibility of FA-diets is not clear. There were no differences in rumen pH (Huhtanen et al. 1997b) which could explain differences in NDF digestibility. The lower NDF digestibility of FA-diets may be attributed to a high WSC content, which may depress cellulolytic activity in the rumen. Intraruminal sugar infusions have depressed ruminal fibre digestibility without affecting rumen $\mathrm{pH}$ (Rooke et al. 1987, Huhtanen 1987), whereas lactic acid had no effect on fibre digestion (Jaakkola and Huhtanen 1992). However, an in vitro study with continuous fermentors (Nousiainen et al. 1996) suggested that FA treatment can also depress fibre digestibility when silage soluble fractions were removed by washing. Lower NDF content of FA-silage and as high WSC content in silage as in grass before ensiling indicate hydrolysis of more readily digestible hemicellulose in the silo, such that the residue might be expected to be of a lower digestibility. However, assuming a similar NDF content in FA-silage to that in I-silage would only slightly reduce differences in NDF digestibility (from 0.605 vs. 0.647 to 0.618 vs. 0.647 ).

Restricted fermentation of FA-silage increased silage DM intake by $0.53 \mathrm{~kg} / \mathrm{d}$ compared with I-silage. No significant difference in silage DM intake was observed between wilted FAtreated and enzyme/inoculant-treated silages 


\section{AGRICULTURAL AND FOOD SCIENCE IN FINLAND}

Vol. 7 (1998): 329-343.

when the difference in the extent of the fermentation between the silages was smaller than in the present study (Jaakkola et al. 1996). The decrease in silage DM intake in the present study can be attributed to the higher lactic acid concentration since other fermentation parameters were not affected. The adverse effect of silage lactic acid on intake is in line with observations of Thomas et al. (1980) and Choung and Chamberlain (1993). However, our study and that of Choung and Chamberlain (1993) do not support the hypothesis of Thomas et al. (1980) that the adverse effect of lactic acid on silage DM intake can be overcome by feeding protein supplements, for silage intake increased similarly with FA- and I-silage with increasing FM. When extensively fermented unwilted silages had higher lactic acid content or also contained more ammonia $\mathrm{N}$ and VFA than their formic acid treated counterpart, the difference in silage DM intake was greater than in the present study (Heikkilä et al. 1989, 1991, 1993). However, fermentation characteristics do not always explain differences in silage DM intake. For example, Gordon (1989) and Mayne (1990) reported higher DM intakes with inoculated silage than with untreated or FA-silage in the absence of marked changes in fermentation pattern. Our results suggest that silage DM intake is limited by at least two factors, lactic acid and 'a protein responsive factor' (Figure 2). An increase in silage DM intake results from effects of FM on the protein responsive factor while lactic acid continues to constrain the intake of I-silage below that of FAsilage. Increased NDF digestibility with FM inclusion suggest that the mechanism by which protein responsive factor increases intake, is increased rate of digestion in the rumen. However, the higher NDF digestibility of diet based on I-silage suggest that the lactic acid constraint is related to some other factors. When the AAT intake was corrected for the lower efficiency of microbial synthesis with I-silage than with FAsilage (Huhtanen et al. 1997), the relationship between AAT content of the diet and silage DM intake was very close. This suggests that the mechanism of the lactic acid constraint is a re-
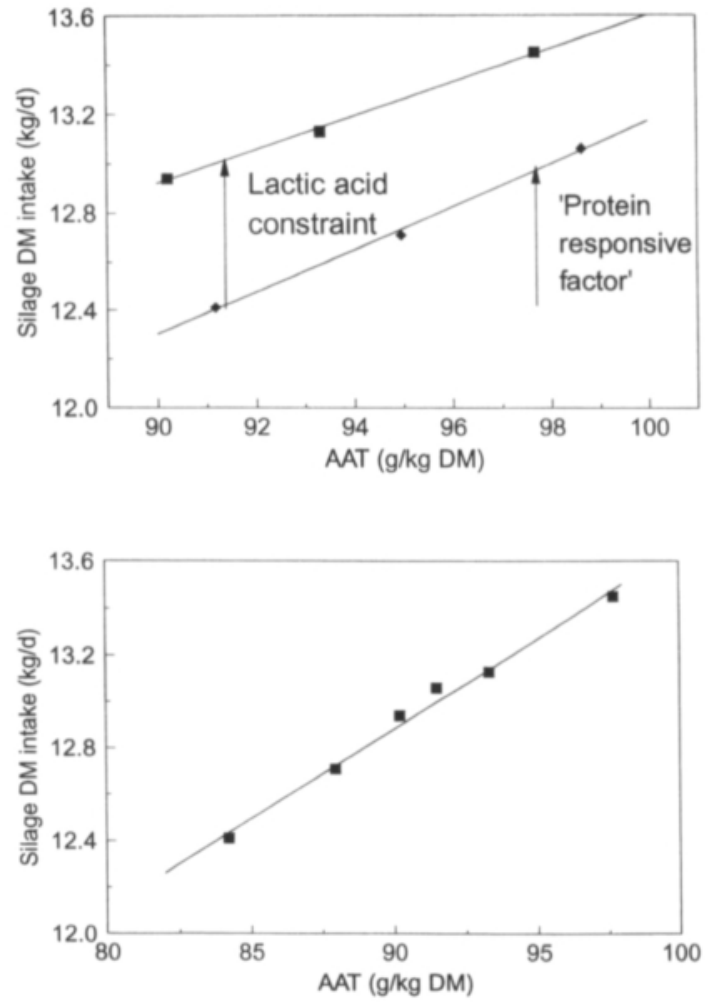

Figure 2. Relationship between uncorrected (above) and corrected dietary AAT content and silage DM intake. Silage DM intake was corrected for differences in concentrate intake assuming a substitution rate of 0.5 .

duced amino acid to energy ratio at tissue level.

There were no significant differences in milk yield between the formic acid and inoculated silages, which is in agreement with other experiments (Chamberlain et al. 1992, Heikkilä et al. 1991, Mayne 1993, Jaakkola et al. 1996, Keady and Murphy 1996). However, Gordon (1989) and Mayne (1990) reported a higher milk yield in cows given inoculated silage than in those given FA-treated silage, even when differences in silage fermentation were small. It should, however, be noted that in their studies the rate of formic acid application was 2.3-3.4 1/t, whereas in Finnish studies the application rate has been 4 $5 \mathrm{l} / \mathrm{t}$.

In agreement with the literature review of van Vuuren et al. (1995) restricting the extent of si- 


\section{AGRICULTURAL AND FOOD SCIENCE IN FINLAND}

\section{Heikkilä, T. et al. Extent of silage fermentation and protein supplementation in cows}

lage fermentation by using formic acid increased milk fat content. Higher milk fat content in cows fed FA-silages can be attributed to the higher ratio of lipogenic (acetate and butyrate) to glucogenic (propionate) VFA in the rumen (Chamberlain and Choung 1993, van Vuuren et al. 1995). This ratio was markedly higher with FAsilage than with I-silage ( 4.6 vs. 3.6$)$ when the same silages used in the present study were used in another study (Huhtanen et al. 1997b). Silage lactic acid increases the proportion of propionate in rumen VFA (Robertson et al. 1993, Martin et al. 1994, van Vuuren et al. 1995), whereas silage WSC increase either acetate (Martin et al. 1994, Huhtanen et al. 1997b) or butyrate (Jaakkola et al. 1991, 1993, Smith et al. 1993).

Slightly higher milk protein content $(\mathrm{P}=0.12)$ in cows given FA-treated silage than in those given I-silage is consistent with many other studies examining the effects of silage fermentation on milk production (Heikkilä et al. 1989, 1991, Chamberlain et al. 1992, Smith et al. 1993). Higher milk protein content with restrictively compared with extensively fermented silage can partly be attributed to increased silage DM intake and partly to increased protein supply from higher rumen microbial protein synthesis with FA-treated silage (see van Vuuren et al. 1995). With the present silages, microbial protein production estimated from urinary excretion of purine derivatives was about $10 \%$ higher with FAsilage than with I-silage (Huhtanen et al. 1997b).

Lower lactose content in milk with FA-treated silage may be attributed to the higher lipogenic to glucogenic ratio in rumen VFA. Increasing the proportion of butyrate in VFA-mixture infused into the rumen has consistently decreased milk lactose content (Miettinen and Huhtanen 1996, Huhtanen et al. 1997a). However, differences in milk lactose content have been small, although statistically significant, and are probably of minor practical importance.

Differences in milk fatty acid composition between the silages were generally small. Higher proportions of short-chain fatty acids with inoculated silage than with FA-silage are largely similar to those reported by Chamberlain et al. (1992) between restrictively and extensively fermented silages fed with a barley supplement. In the present study FA treatment increased the proportions of all $\mathrm{C}_{18}$ fatty acids compared with I-treatment. In agreement, Chamberlain et al. (1992) reported higher proportions of stearic acid with FA-treated silage, but in their study oleic or linoleic acid were not affected by the extent of silage fermentation. Higher proportions of oleic and linoleic acid in milk fat in this study suggest that the fatty acids of grass were less influenced by ensiling in FA-treated silage than in I-silage.

Lower plasma glucose and higher blood BHB in cows fed on FA-diets than in those fed on Idiets is in accord with the data of Smith et al. (1993), Mayne (1993), Miettinen and Huhtanen (1997), and can be attributed to differences in rumen fermentation pattern. The supply of the most important glucose precursor, propionate, was markedly lower from FA-diets than from Idiets as indicated by the lower molar proportion of propionate (Huhtanen et al. 1997b). These observations suggest that with restrictively fermented silages the supply of glucose precursors is less than with extensively fermented silages. Lower milk lactose content is in line with this hypothesis. Since feeding of FA-silage was not associated with reduced feed intake, rather vice versa, it is not likely that the increase in blood BHB resulted from endogenous ketogenesis. A more likely explanation is a greater proportion of lipogenic VFA in the rumen with FA-silage compared with I-silage. Increased milk and plasma urea content may be explained by increased absorption of ammonia $\mathrm{N}$ from the rumen with I-diet compared with FA-diet as indicated by the decrease in the efficiency of microbial protein synthesis (Huhtanen et al. 1997b). Also lower N digestibility with FA-diets may partly explain the lower milk urea content with FA-treated silage.

\section{Effects of protein supplementation}

The response to FM supplementation was relatively small. The mean response of $0.11 \mathrm{~g}$ of milk protein/g increase in CP intake was smaller than the corresponding response reported by Cham- 


\section{AGRICULTURAL AND FOOD SCIENCE IN FINLAND}

Vol. 7 (1998): 329-343.

berlain et al. (1989) for cows given FM supplements. Also in our recent study with rapeseed meal supplementation (Huhtanen and Heikkilä 1996) better marginal responses to protein were obtained than in the present study. The small response to protein supplementation despite high production level in the present study may be related to the high quality of forages used and consequently, to efficient microbial protein production in the rumen (FA- vs. I-silage, 22.7 vs. 20.3 g microbial N/kg DOM). Reduced milk lactose content in cows given FM supplementation is in agreement with the data of Broderick (1992) and Huhtanen (1993).

In contrast to earlier studies (Chamberlain et al. 1989, Huhtanen 1993), FM supplementation did not improve the utilisation of ME for milk production. This may be due to the high $k_{l}$ value (0.635) with the basal diet without FM in the present study, whereas in the other studies the corresponding $k_{l}$ values were considerably lower than the value of 0.62 proposed for the efficiency of ME utilisation for milk production. Therefore there was less scope to improve ME utilisation by protein supplementation.

\section{Interactions between the silage fermenta- tion and protein supplementation}

Production responses to FM supplementation tended to depend on the silage fermentation characteristics. The reasons for higher increases in milk fat content and yield with FA-silage than Isilage in response to FM supplementation are not clear. ECM yield tended to increase more and utilisation of ME for milk production improved more $(0.019$ vs. -0.016$)$ in cows given FA-silage than in those given I-silage. This observation is in accord with the suggestion of Chamberlain and Choung (1993) that, with restrictively fermented silages, the responses to protein supplementation are more related to repartitioning between milk and body tissues than to increased silage DM intake. However, changes in blood BHB and milk fatty acid composition with increasing FM do not indicate any major differ- ences between silages in mobilisation of body tissues with increasing level of FM. Repartitioning may have occurred simply by less deposition of body tissue.

Milk protein yield responses to $\mathrm{FM}_{120}$ inclusion tended to be greater with I-silage than with FA-silage (100 vs. $60 \mathrm{~g} / \mathrm{d})$. This supports the hypothesis of increased supply of amino acids from restrictively fermented silage compared with high lactate silage. The efficiency of microbial protein synthesis was higher with restrictively fermented silage compared with high lactate silage (Huhtanen et al. 1997b), and therefore less benefits may be expected from protein supplementation with restrictively fermented silage. The supply of glucose from ruminal propionate production is smaller with restrictively fermented silages than with high lactate silages as indicated by the lower plasma glucose concentration in the present study. Greater glucose supply from silage lactate may reduce utilisation of amino acids for gluconeogenesis, and more amino acids may be available for milk protein synthesis. Reduced milk protein yield when propionate was replaced isoenergetically with butyrate (Miettinen and Huhtanen, 1996, Huhtanen et al. 1997a) indicate that differences in ruminal fermentation pattern affect utilisation of dietary amino acids for milk protein synthesis. Propionate has also increased nitrogen retention in sheep (Ørskov et al. 1979). The lack of response to the first level of FM with FA-silage is unclear. It would seem that, at the zero level of FM, there is no shortage of glucose precursors with FA-silage because, at the same ME intake as with I-silage, it supports a higher milk protein yield. It may be that the supply of glucose precursors becomes limiting as FM inclusion begins, and the response to $\mathrm{FM}_{60}$ is reduced correspondingly.

Unbalanced amino acid composition of microbial protein is another alternative explanation for limited effects of protein supplementation of restrictively fermented silage on milk protein yield. In this context, it is noteworthy that, with the same silages used in another experiment that allowed a comparison of the response to restriction of silage fermentation with the response to 


\section{AGRICULTURAL AND FOOD SCIENCE IN FINLAND}

\section{Heikkilä, T. et al. Extent of silage fermentation and protein supplementation in cows}

postruminal infusion of casein, whereas both treatments increased plasma concentrations of lysine and branched-chain amino acids, but only casein infusion increased plasma concentrations of histidine (Miettinen and Huhtanen 1997) and milk protein yield (Huhtanen et al 1997b). With silage based diets histidine appears to be the first limiting amino-acid for milk protein production (Vanhatalo et al. 1997). With FA-silage a greater proportion of supplementary protein was probably used for gluconeogenesis than with I-silage (see Miettinen and Huhtanen 1997). It would appear that in our study the better protein value of restrictively fermented silage was partly offset by increased utilisation of amino acids for gluconeogenesis.

In other studies more distinct differences in the response to protein supplementation with different forages have been found. Choung and Chamberlain (1992) reported a significantly greater response to postruminal casein infusion with untreated silage than with enzyme-treated silage. Similarly, FM supplementation increased milk protein yield more with lucerne silage than with lucerne hay (Broderick 1995).

\section{Conclusions}

In the conditions of the present study, both formic acid and bacterial inoculant produced silages of good fermentation quality. FA-treatment decreased diet digestibility and especially that of NDF compared with inoculated silage. Feeding more extensively fermented I-silage decreased silage DM intake, but had no effects on milk or milk protein yields. Milk fat content and fat yield were higher with FA-silage than with Isilage. Responses to protein supplementation would seem to be different between the silages. From the results of the present study and other studies conducted with the same silages it can be concluded that restriction of silage fermentation increases the supply of lipogenic VFA and amino acids. High lactate silages provide more glucose precursors from rumen fermentation but are more limited in amino acids than restrictively fermented silages. Since glucose supply was lower with FA-diets, improved protein value of restrictively fermented silage may not have been completely realized in terms of milk protein yield. The results of the present trial suggest that optimal supplementation of grass silage may depend on the extent of silage fermentation, but more work is needed to fully understand interactions between silage fermentation and concentrate supplementation to optimise supplementation of different silage types. More work is also needed to understand the mechanisms affecting cell wall digestibility of silages.

Acknowledgements. The authors thank Valio Ltd. for an inoculant additive. We appreciate the staff of Jokioinen estate Lintupaju farm and dairy barn for technical assistance and our laboratory and other staff for laboratory analysis and calculations.

\section{References}

Broderick, G.A. 1992. Relative value of fish meal versus solvent soybean meal for lactating dairy cows fed alfalfa silage as sole forage. Journal of Dairy Science 75: 174-183.

- 1995. Performance of lactating dairy cows fed either alfalfa silage or alfalfa hay as the sole forage. Journal of Dairy Science 78: 320-329.

Chamberlain, D.G. 1987. The silage fermentation in relation to the utilization of nutrients in the rumen. Process Biochemistry 22: 60-63.
- \& Choung, J.-J. 1993. The nutritional value of grass silage. In: O'Kiely, P. et al. (eds.). Silage research 1993. Proceedings of the 10th International Conference on Silage Research, Dublin City University, Ireland, 6-8 September 1993. p. 131-136.

- , Martin, P.A. \& Robertson, S. 1989. Optimizing compound feed use in dairy cows with high intakes of silage. In Haresign, W. \& Cole, D.J.A. (eds.). Recent Advances in Animal Nutrition. Butterworths, London. p. 175-193. 
Vol. 7 (1998): 329-343.

- Martin, P.A., Robertson, S. \& Hunter, E.A. 1992. Effects of the type of additive and the type of supplement on the utilization of grass silage for milk production in dairy cows. Grass and Forage Science 47: 391-399.

- \& Quig, J. 1987. The effects of the rate of addition of formic acid and sulphuric acid on the ensilage of perennial ryegrass in laboratory silos. Journal of the Science of Food and Agriculture 38: 217-228.

Choung, J.-J. \& Chamberlain, D.G. 1992. The effect of the addition of cell-wall degrading enzymes at ensiling on the response to postruminal supplementation of protein in dairy cows receiving a silage-based diet. Journal of the Science of Food and Agriculture 60: 525-527.

- \& Chamberlain, D.G. 1993. Effects of addition of lactic acid and post-ruminal supplementation with casein on the nutritional value of grass silage for milk production in dairy cows. Grass and Forage Science 48: $380-386$.

Davis, A.W. \& Hall, W.B. 1969. Cyclic change-over designs. Biometrika 56: 283-293.

Gordon, F.J. 1989. An evaluation through lactating cattle of a bacterial inoculant as an additive for grass silage. Grass and Forage Science 44: 169-179.

Heikkilä, T., Toivonen, V. \& Väätäinen, H. 1991. Effect of biological additives on silage quality and milk production with dairy cows. 42 nd Annual Meeting of the EAAP, 2-12 September, Berlin, Germany. Abstracts Vol 2, p. 49.

- , Văătăinen, H. \& Lampila, M. 1989. Effect of silage quality on milk yield and composition in dairy cows. Proceedings of the International Symposium on Production, Evaluation and Feeding of Silage. 12-16 June 1989, Rostock. p. 177-183.

- , Văătăinen, H. \& Toivonen, V. 1993. Effects of acid and biological additives on grass silage quality and milk production in dairy cows supplemented with concentrates containing three levels of rapeseed meal. In: O'Kiely, P. et al. (eds.). Silage research 1993. Proceedings of the 10th International Conference on Silage Research, Dublin City University, Ireland, 68 September 1993. p. 190-191.

Huhtanen, P. 1987. The effects of intraruminal infusions of sucrose and xylose on nitrogen and fibre digestion in the rumen and intestines of cattle receiving diets of grass silage and barley. Journal of Agricultural Science in Finland 59: 405-424.

- 1993. The effects of concentrate energy source and protein content on milk production in cows given grass silage ad libitum. Grass and Forage Science 48: 347-355.

- Blauwiekel, R. \& Saastamoinen, I. 1997a. Effects of intraruminal infusions of propionate and butyrate with two different protein supplements on milk production and blood metabolites in dairy cows receiving grass silage-based diet. Journal of the Science of Food and Agriculture 77: 213-222.

- \& Heikkilä, T. 1996. Effects of physical treatment of barley and rapeseed meal in dairy cows given grass silage-based diets. Agricultural and Food Science in Finland 5: 399-412.
- , Miettinen, H.O. \& Toivonen, V.F.J. 1997b. Effects of silage fermentation and post-ruminal casein supplementation in lactating dairy cows. 1. Diet digestion and milk production. Journal of the Science of Food and Agriculture 74: 450-458.

Huida, L. 1982. Gas chromatographic determination of water and ethanol in silage by internal standard method. Journal of the Scientific Agricultural Society of Finland 54: 137-143.

Jaakkola, S. \& Huhtanen, P. 1992. Rumen fermentation and microbial protein synthesis in cattle given intraruminal infusions of lactic acid with a grass silage based diet. Journal of Agricultural Science, Cambridge 119: 411-418.

-, Huhtanen, P. \& Hissa, K. 1991.The effect of cell wall degrading enzymes or formic acid on fermentation quality and on digestion of grass silage by cattle. Grass and Forage Science 46: 75-87.

-, Huhtanen, P. \& Kaunisto, V. 1993. VFA proportions and microbial protein synthesis in the rumen of cattle receiving grass silage ensiled with different rates of formic acid. In: O'Kiely, P. et al. (eds.). Silage research 1993. Proceedings of the 10th International Conference on Silage Research, Dublin City University, Ireland, 6-8 September 1993. p. 139-140.

-, Rinne, M., Huuskonen, K., Vesterinen, V. \& Huhtanen, P. 1996. The effect of silage fermentation on the response to protein supplementation in milk production and rumen fermentation in vitro. In: Nunes, A.F. et al. (eds.). Protein Metabolism and Nutrition. Proceedings of the 7th International Symposium on Protein Metabolism and Nutrition, Vale de Santerem, Portugal, 24-27 May 1995. EAAP Publication no. 81. p. 235-236.

Keady, T.W. J. \& Murphy, J.J. 1996. Effects of inoculant treatment on ryegrass silage fermentation, digestibility, rumen fermentation, intake and performance of lactating dairy cattle. Grass and Forage Science 51: 232-241.

- \& Murphy, J.J. 1997. The effects of treating low dry matter herbage with a bacterial inoculant or formic acid on the intake and performance of lactating dairy cattle. Animal Science 64: 25-36.

Martin, P.A., Chamberlain, D.G., Robertson, S. \& Hirst, D. 1994. Rumen fermentation patterns in sheep receiving silages of different chemical composition supplemented with concentrates rich in starch or digestible fibre. Journal of Agricultural Science, Cambridge 122: 145-150.

Mayne, C.S. 1990. An evaluation of an inoculant of Lactobacillus plantarum as an additive for grass silage for dairy cattle. Animal Production 51: 1-13.

- 1993. The effect of formic acid, sulphuric acid and a bacterial inoculant on silage fermentation and the food intake and milk production of lactating dairy cows. Animal Production 56: 29-42.

Miettinen, H. \& Huhtanen, P. 1996. Effects of the ratio of ruminal propionate to butyrate on milk yield and blood metabolites in dairy cows. Journal of Dairy Science 79: 851-861.

- \& Huhtanen, P.J. 1997. Effects of silage fermentation and post-ruminal casein supplementation in lac- 


\section{AGRICULTURAL AND FOOD SCIENCE IN FINLAND}

Heikkilä, T. et al. Extent of silage fermentation and protein supplementation in cows

tating dairy cows. 2. Energy metabolites and plasma amino acids. Journal of the Science of Food and Agriculture 74: 459-468.

Ministry of Agriculture, Food and Fisheries (MAFF). 1984. Energy allowances and feeding systems for ruminants. Reference Book 433. Her Majesty's Stationery Office, London. $85 \mathrm{p}$.

Nousiainen, J., Saarisalo, E. \& Jaakkola, S. 1996. The effect of additives on the rumen metabolism of intact or washed grass silages in continuous cultures. In: Jones, D.I.H. et al. (eds.). Proceedings of the 11th International Silage Conference, University of Wales, Aberystwyth, 8-11 September 1996. p. 96-97.

Ørskov, E.R., Grubb, D.A., Smith, J.S., Webster, A.J.F. \& Corrigall, W. 1979. Efficiency of utilization of volatile fatty acids for maintenance and energy retention by sheep. British Journal of Nutrition 41: 541-551.

Rauramaa, A., Tommila, A., Nousiainen, J. \& Toivonen, V. 1996. The effect of Lactobacillus rhamnosus and Propionibacterium freudenreichii ssp. shermanii on chemical and microbial composition of prewilted silages. In: Jones, D.I.H. et al. (eds.). Proceedings of the 11th International Silage Conference, University of Wales, Aberystwyth, 8-11 September 1996. p. 242-243.

Robertson, S., Chamberlain, D.G. \& Choung, J.-J. 1993. Effects of silage composition on rumen fermentation and the urinary output of purine derivatives in sheep. In: O'Kiely, P. et al. (eds.). Silage research 1993. Proceedings of the 10th International Conference on Silage Research, Dublin City University, Ireland, 68 September 1993. p. 164-165.

Rooke, J.A., Lee, N.H. \& Armstrong, D.G. 1987. The effects of intraruminal infusions of urea, casein, glucose syrup and a mixture of casein and glucose syrup on nitrogen digestion in the rumen of cattle receiving grass-silage diets. British Journal of Nutri- tion 57: 89-98.

SAS Institute Inc, 1989. SAS/STAT user's guide. Version 6 Fourth Edition, Vol 2, Cary, NC. 846 p.

Sjaunja, L.O., Baevre, L., Junkkarinen, L., Pedersen, J. \& Setälä, J. 1990. A Nordic proposal for an energy corrected milk (ECM) formula. 27th Session International Committee of Recording and Productivity of Milk Animal. Paris, France. p. 156-157.

Smith, E.J., Henderson, A.R., Oldham, J.D., Whitaker, D.A., Aitchison, K., Anderson, D.H. \& Kelly, J.M. 1993. The influence of an inoculant/enzyme preparation as an additive for grass silage offered in combination with three levels of concentrate supplementation on performance of lactating dairy cows. Animal Production 56: 301-310.

Thomas, C., Gill, M. \& Austin, A.R. 1980. The effect of supplements of fishmeal and lactic acid on voluntary intake of silage by calves. Grass and Forage Science 35: 275-279.

Tuori, M., Kaustell, K., Valaja, J., Aimonen, E., Saarisalo, E. \&Huhtanen, P. 1996. Rehutaulukot ja ruokintasuositukset. (Feed Tables and Feeding Recommendations). Helsinki. 99 p. (in Finnish).

Vanhatalo, A., Huhtanen, P. \& Varvikko, T. 1997. Response of dairy cows fed grass silage based diets to the abomasal infusions of histidine alone or in combinations with methionine and lysine. In: ADSA '97, Program and abstracts, 92nd annual meeting, University of Guelph, June 22-25, 1997. Journal of Dairy Science 80, Supplement 1, P441. p. 257.

van Vuuren, A.M., Huhtanen, P. \& Dulphy, J.-P. 1995. Improving the feeding and health value of ensiled forages. In: Journet, M. et al. (eds). Recent Developments in the Nutrition of Herbivores. Proceedings of the IVth International Symposium on the Nutrition of Herbivores, Clermont-Ferrand, France, 11-15 September, 1995. p. 279-307, INRA Editions, Paris. 
Vol. 7 (1998): 329-343.

\title{
SELOSTUS
}

\author{
Säilörehun käymisasteen ja valkuaistäydennyksen vaikutus maidon tuotantoon \\ Terttu Heikkilä, Vesa Toivonen ja Pekka Huhtanen \\ Maatalouden tutkimuskeskus
}

Tutkimuksessa selvitettiin säilörehun käymisasteen ja väkirehun valkuaistason vaikutusta säilörehun syöntiin, maidon tuotantoon, maidon koostumukseen, rehuannoksen sulavuuteen ja veriarvoihin. Kokeessa oli 12 Ayrshire-lehmää ja kuusi koeruokintaa. Tutkittavina oli kaksi esikuivattua säilörehua, jotka säilöttiin bakteeriympillä (Lactobacillus rhamnosus ja Propionibacterium freudenreichii ssp. shermanii), $5 \times 10^{6}$ pmy/g ruohoa (ymppi) tai AIV 2:lla $5 \mathrm{l} / \mathrm{tn}$ (happo) sekä kolme väkirehun valkuaispitoisuutta (raakavalkuaista 129, 169, $211 \mathrm{~g} / \mathrm{kg} \mathrm{ka),} \mathrm{jotka} \mathrm{valmistettiin}$ korvaamalla kalajauholla 0,60 ja 120 g/kg kauraohra-melassileike-kivennäisseoksesta. Säilörehua annettiin vapaasti ja väkirehua $10 \mathrm{~kg} / \mathrm{pv}$.

Molemmat säilörehut olivat laadultaan hyviä. Ymppirehu oli huomattavasti enemmän käynyttä kuin happorehu, mitä osoitti suurempi maitohappo- (132 vs $35 \mathrm{~g} / \mathrm{kg} \mathrm{ka)} \mathrm{ja} \mathrm{pienempi} \mathrm{sokeripitoisuus} \mathrm{(61} \mathrm{vs}$ 160). Happorehuannoksen orgaanisen aineen, raakavalkuaisen ja neutraalidetergenttikuidun sulavuus oli huonompi kuin ymppirehuannoksen. Kalajauho lisäsi rehuannoksen sulavuutta. Lehmät söivät happorehua enemmän kuin ymppirehua (13.35 vs $12.82 \mathrm{~kg}$ $\mathrm{ka} / \mathrm{pv}$ ), mutta maitotuotoksissa ei ollut eroa (33.2 vs
$33.5 \mathrm{~kg} / \mathrm{pv})$. Energiakorjattu maito- (36.4 vs. $35.4 \mathrm{~kg} /$ pv) ja rasvatuotos (1558 vs $1465 \mathrm{~g} / \mathrm{pv})$ olivat happorehulla suuremmat kuin ymppirehulla, sillä happorehulla tuotetun maidon rasvapitoisuus oli suurempi kuin ymppirehulla tuotetun (47.1 vs $44.0 \mathrm{~g} / \mathrm{kg}$ ). Maidon valkuaispitoisuudessa ja -tuotoksessa ei ollut eroa rehujen välillä (33.0 vs $32.5 \mathrm{~g} / \mathrm{kg}$ ja 1091 vs $1087 \mathrm{~g} /$ pv). Kalajauho lisäsi säilörehun syöntiä, maito- ja valkuaistuotosta sekä maidon valkuaispitoisuutta. Valkuaislisän vaikutus riippui säilörehun käymisasteesta. Runsaan kilon (1.2 kg) kalajauholisä lisäsi rasvatuotosta enemmän happo- kuin ymppirehulla (122 vs $23 \mathrm{~g} / \mathrm{pv}$ ), kun taas valkuaistuotos nousi enemmän ymppirehulla (100 vs $60 \mathrm{~g} / \mathrm{pv}$ ). Happorehulla ruokitun lehmän plasman glukoosi- sekä maidon ja veren ureapitoisuudet olivat pienemmät ja veren $\beta$-hydroksivoihappopitoisuus oli suurempi kuin ymppirehulla ruokitun lehmän. Tulokset viittaavat siihen, että optimitäydennys riippuu säilörehun käymisasteesta, mutta lisätutkimuksia vaaditaan säilörehun käymisasteen ja väkirehutäydennyksen välisten yhdysvaikutusten sekä säilörehun kuidun sulatukseen vaikuttavien tekijöiden selvittämiseksi. 